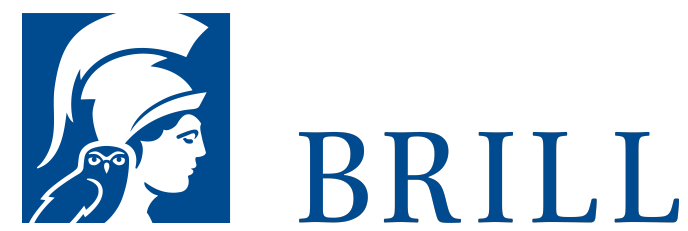

\title{
Himmlers Krieger
}

Joachim Peiper und die Waffen-SS in Krieg und Nachkriegszeit.

2. Auflage

Author: Jens Westemeier

Ein eindrucksvolles Buch über die zwei Karrieren des SSStandartenführers Joachim Peiper (1915-1976). Die erste führte den »Vorzeigeoffizier« der Waffen-SS in den engsten Kreis um Himmler, dessen Adjutant er von 1938 bis 1941 war. Bis Kriegsende stieg der Liebling des Reichsführers-SS zum hochdekorierten Regimentskommandeur in der 1. SSPanzerdivision Leibstandarte Adolf Hitler auf. In seiner zweiten Karriere nach dem Krieg, die bislang fast völlig im Dunkeln lag, gelangte Peiper bei Porsche in nächste Nähe der Chefetage. Eine einflussreiche Lobby hatte den wegen des Massakers von Malmedy zunächst zum Tode Verurteilten zum Helden und zum »Opfer der Siegerjustiz« stilisiert. Über seinen geheimnisumwitterten Tod hinaus blieb er bis heute eine Ikone aller Apologeten von Himmlers Kriegern. Gestützt auf eine Fülle von bisher unbekanntem Material demontiert Jens Westemeier den »Mythos Peiper« und mit ihm den der Waffen-SS. Und er zeigt überdies, wie und warum in der jungen Bundesrepublik schon bald eine Vergangenheitspolitik des Vergessens und Verzeihens betrieben wurde. Seine Arbeit wurde 2012 mit dem Werner-Hahlweg-Preis für Militärgeschichte ausgezeichnet.

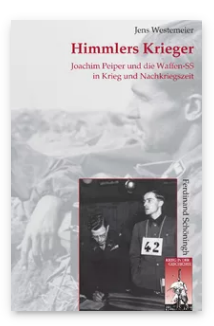

Pages: 882 Seiten, $30 \mathrm{~s} / \mathrm{w}$

Abb.

Language:

German

Subjects:

Contemporary

History, History

Publisher: Brill|

Schöningh

Series:

Krieg in der

Geschichte,

Volume: 71

E-Book (PDF)

Released online:

26 Nov 2019

ISBN: 978-3-

657-78508-7

List price

Paperback

Publication date:

22 Mar 2019

ISBN: 978-3-

506-785०8-4

List price 
Jens Westemeier ist seit 2016 als wissenschaftlicher Mitarbeiter an der Universitätsklinik RWTH Aachen tätig.

For more information see brill.com

\author{
Order information: Order online at brill.com \\ +44330 333 0049 | customerservices@brill.com \\ Submission information: brill.com/authors
}

Titles published by Brill | Fink, Brill | mentis or Brill | Schöningh:

+49(o)71 5413279216 | brill@brocom.de 